\title{
Vocational training and sexual assault against women: challenges for graduation in nursing ${ }^{\circ}$
}

\author{
Formação profissional e violência sexual contra a mulher: desafios para a graduação em enfermagem \\ Formación profesional y violencia sexual contra la mujer: desafíos para la graduación en enfermería
}

Francisca Alanny Rocha Aguiar ${ }^{1,2}$ (])

Raimunda Magalhães da Silva² ${ }^{2}$ Indara Cavalcante Bezerra² (B)

Luiza Jane Eyre de Souza Vieira² (10)

Ludmila Fontenele Cavalcanti ${ }^{3}$ (i)

Antonio Rodrigues Ferreira Júnior ${ }^{4}$ (D)

1. Centro Universitário INTA - UNINTA. Sobral, CE, Brasil.

2. Universidade de Fortaleza, Programa de Pós-Graduação em Saúde Coletiva. Fortaleza, CE, Brasil.

3. Universidade Federal do Rio de Janeiro, Programa de Pós Graduação em Serviço Social. Rio de Janeiro, RJ, Brasil.

4. Universidade Estadual do Ceará, Programa de Pós-Graduação em Saúde Coletiva. Fortaleza, CE, Brasil.
Corresponding author:

Francisca Alanny Rocha Aguiar.

E-mail: alannyrocha2009@hotmail.com

Submitted on 09/05/2019.

Accepted on 11/09/2019.

DOI: 10.1590/2177-9465-EAN-2019-0135

\section{Abstract}

Objectives: To understand the meanings of sexual assault against women in the point of view of students, professors and university managers of undergraduate nursing; and to understand how the contents on this subject are approached in undergraduate courses in Nursing in Higher Education Institutions. Method: A qualitative study, with data collection from March to November 2018, through interviews with ten students, ten teachers and seven managers from two private institutions. Data was treated by the modality of thematic content, with a theoretical-analytical reference of 'gender violence' and 'rape culture'. Results: The topic is approached in a fragmented way in different academic contexts, which leads to the reflection of the topic in the training of nurses, extending to their professional performance. Conclusion and implications for practice: The possibilities of incorporating the subject in the teaching-learning scenarios and practices converge to approach the content about the different types of violence in the undergraduate subjects, with educational actions with the population, potentializing the deconstruction of the culture of female subordination. In addition, the study is aligned with the appropriate time in which the reorientation of the curricular guidelines for the health courses is discussed.

Keywords: Violence against women; Education, Higher; Professional training.

\section{Resumo}

Objetivos: Compreender os sentidos da violência sexual contra a mulher na visão de alunos, professores e gestores universitários da graduação em Enfermagem; e entender de que modo os conteúdos sobre esta temática são abordados nos cursos de graduação em Enfermagem nas Instituições de Ensino Superior. Método: Estudo qualitativo, cuja coleta de dados ocorreu no período de março a novembro de 2018, por meio de entrevistas com dez discentes, dez docentes e sete gestores de duas Instituições privadas. Os dados foram tratados pela modalidade de conteúdo temática, com referencial teórico-analítico da 'violência de gênero' e 'cultura do estupro'. Resultados: O tema é abordado de forma fragmentada em diferentes contextos acadêmicos, o que leva à reflexão da temática na formação do enfermeiro, estendendo-se à sua atuação profissional. Conclusão e implicações para a prática: As possibilidades de incorporação do tema nos cenários de ensino-aprendizagem e nas práticas convergem para a abordagem do conteúdo sobre os diferentes tipos de violência nas disciplinas da graduação, com ações educativas junto à população potencializando a desconstrução da cultura de subordinação feminina. Ademais, o estudo alinha-se ao momento oportuno em que se discute a reorientação das diretrizes curriculares para os cursos da saúde.

Palavras-chave: Violência contra a mulher; Educação superior; Formação profissional.

\section{Resumen}

Objetivos: Comprender el significado de la violencia sexual contra las mujeres en opinión de estudiantes, profesores y directores universitarios de enfermería de pregrado; y comprender cómo se abordan los contenidos sobre este tema en los cursos de pregrado en Enfermería en instituciones de educación superior. Método: Estudio cualitativo, cuya recopilación de datos tuvo lugar de marzo a noviembre de 2018, a través de entrevistas con diez estudiantes, diez maestros y siete gerentes de dos instituciones privadas. Los datos se trataron con la modalidad de contenido temático, con una referencia teórico-analítica de "violencia de género" y "cultura de violación". Resultados: El tema se aborda de una manera gradual en diferentes contextos académicos lo que lleva al tema de la reflexión en la educación de enfermería, que se extiende a sus actividades profesionales. Conclusión y implicaciones para la práctica: El tema de oportunidades de fusión en escenarios de enseñanza y aprendizaje y prácticas convergen sobre el contenido de la aproximación a los diferentes tipos de violencia en las disciplinas de grado con actividades educativas entre la población, el aumento de la deconstrucción de la subordinación femenina de la cultura. Además, el estudio está alineado con el momento oportuno en el que se discute la reorientación de las pautas curriculares para los cursos de salud.

Palabras clave: Violencia contra la Mujer; Educación Superior; Capacitación Profesional. 


\section{INTRODUCTION}

The discussion about gender violence against women has become of great importance in the world, from countless situations experienced by this population. Understanding this phenomenon challenges research centers in several countries, especially in trying to contribute to governments in addressing them. ${ }^{1-4}$ Throughout history, violence against women has been an active instrument of discrimination that has allowed the construction, consolidation and solidification of this inequality in order to gain control, subordination and prevent its full emancipation. ${ }^{1-5}$

Accordingly, the Inter-American Convention on the 'Prevention, Punishment, and Eradication of Violence Against Women' assumes that such violence corresponds to any action or conduct based on gender, causing death, harm or physical, sexual or psychological distress to women, both publicly and privately. $^{5}$

Recognizing the complexity of this confrontation is fundamental. The study was conducted with 11 district nurses at Primary Health Care Centers in Stockholm, Sweden, about the last time these professionals had seen women in situations of intimate partner violence, showed that participants were hesitant to ask about the occurrence of violence with these women, even if they identified and recognized signs and symptoms of exposure to violence. ${ }^{6}$

Given the scenario of sudden social transformations, broken ties and setbacks in public policies, it is crucial to build dialogs on the theme during the professional training of future nurses who will take care of women in different contexts. ${ }^{7-9}$

Appropriating knowledge about typology, explanations of violence and their repercussions contribute to equate health care and the guarantee of rights, as well as to offer care centered on the person, since violence manifests itself in the most diverse contexts, including of the university environment. ${ }^{10}$ There have been recurring reports in the literature of professionals from the health sector and other public policy sectors about significant gaps in the approach to the topic during vocational training. ${ }^{10,11}$

Based on this finding, it appears that the theme of sexual assault (SA) against women is poorly recognized as part of the content of disciplines offered in undergraduate courses in health. ${ }^{10,11}$ The "rape culture" still present in contemporary society impacts the way society thinks and acts in different contexts.

In this article, the aim was to articulate the theoretical constructs of 'gender violence' advocated by Saffioti ${ }^{12}$ and the 'rape culture' proposed by Sousa. ${ }^{13}$ On gender violence, Saffioti grasps the broader concept, encompassing victims such as women, children and adolescents of both genders, in view of the patriarchal function in which men determine the conduct of other social categories, and receive authorization or tolerance from society. Regarding the 'rape culture', Souza ${ }^{13}$ expresses it as a cluster of symbolic violence that fosters legitimation, tolerance, and the encouragement of sexual rape.
In this context, vocational training carries limitations centered on the clinical-biological paradigm; in a decontextualized permanent education; and in uncritical practice in health services. In this scenario, professional performance in cases of violence is driven by malpractice, improvisation, based on experiences and personal sensitivity, compromising the quality of care provided. ${ }^{14}$

In Brazil, official documents guide the priorities that must be considered in the construction of objectives for citizen education. The framework is the Law of Directives and Bases of National Education (Lei de Diretrizes e Bases, LDB), 1996, and the National and State Curriculum Parameters (1998). In 2001, the National Curriculum Guidelines (Diretrizes Curriculares Nacionais, DCNs) were promulgated as the basis of the pedagogical political project directed to the professional formation. ${ }^{15}$

The DCNs require from undergraduate courses interaction with the social realities and the demands that emanate from them, because it understands education as an instrument for the individual to be recognized as a protagonist in the modification of society and construction of democracy. Thus, it is advised that educational institutions, from basic education to higher education, direct pedagogical projects for human rights. This involvement goes beyond literacy-oriented content, and is mainly concerned with the formation of people. ${ }^{16}$

Invisible issues in the traditional public health analysis, which focus mostly on individual behavior and biological risk factors, are imperative to make up the center of the 2030 global health agenda, such as addressing violence against women, among these, the SA. ${ }^{17,18}$

Although the profile described in the DCNs of the undergraduate Nursing course, advocates the development of competence, skill and attitude of nurses in the health care of women in situations of violence and recognizing the subjectivity inherent in human needs, society demands that Higher Education Institutions (HEls) present professional profiles that respond to complex social demands.

This type of action is combined with technical procedures and qualified care, as it would allow professionals to understand the negative repercussions to women's health in such a unique situation, ${ }^{18}$ directing to integral attention to this woman. Although Brazil has normative, ethical and legal instruments that assure the rights to comprehensive care, such as the Technical Standard ${ }^{19}$ and the "Maria da Penha" law, ${ }^{20}$ attention has not yet been realized, and the curricular matrices in the health field do not satisfactorily contemplate the discussion about gender violence and, even less, about sexual assault.

It is essential to broaden the debates about SA in professional training spaces, especially in societies marked by the reproduction of gender stereotypes and the macho culture. Accordingly, it becomes relevant to identify the conceptions anchored in the curriculum matrices of Nursing courses, a profession that stands out every day in the provision of care. 
Indeed, the curriculum matrices that guide the education of nurses should include reflection and action on the complexity underlying the SA situations, understanding them in the multiple dimensions of this phenomenon. Therefore, investigating the approach of SA against women in the curricula of nursing courses, from the perspective of students, teachers and university managers, will potentiate the renewal of directions and reorientation of pedagogical practices. ${ }^{21}$

Thus, this article intends to: (i) understand the meanings about SA against women in the view of students, teachers and university managers of undergraduate nursing; and (ii) understand how the contents on this theme are addressed in undergraduate nursing courses in higher education institutions.

\section{METHOD}

A qualitative, ${ }^{22}$ descriptive study, which approaches the meanings of SA against women resulting from the participants' experience in the operationalization of the contents of the curriculum matrices and other academic activities in undergraduate nursing.

The study was conducted in two HEls, one located in a municipality in the northern region of the state of Ceará (called $\mathrm{HEI} \mathrm{A)} \mathrm{and} \mathrm{another} \mathrm{in} \mathrm{the} \mathrm{capital} \mathrm{(called} \mathrm{HEI} \mathrm{B).} \mathrm{Twenty-seven}$ members of the Nursing course participated, distributed as follows: five students, seven professors and three university managers from HEI A; five students, five professors and two managers from $\mathrm{HEI} B$. The respondents were unintentionally selected, considering diversity and access to research participants. Participants were invited by email and personal contact, however, all interviews were recorded in person.

Regarding the number of participants, it was initially sought to attend to the systematization of the qualitative research design, of a multicenter character. If necessary, new participants could be invited. However, the pre-analysis revealed the recurrence of content on the interviews, signalizing theoretical saturation on the topic. ${ }^{23}$

The criterion for student participation was to be enrolled from the fifth period and to participate in extracurricular activities, such as research groups, extension, mentoring and scientific initiation. The inclusion of these criteria is justified by the prediction of the researchers that learning through the fifth semester, added to the experience of participating in these activities, broadens the theoretical-practical basis, favoring the student's maturity in analyzing the inclusion or not of the theme under study. Moreover, extension activities are worth mentioning, as recommended by Ordinance No. 1,350/2018, from the Ministry of Education, ${ }^{24}$ which deals with the 'Guidelines for the Extension Policies of Brazilian Higher Education', whose content reaffirms its differential regarding the diffusion of philosophical, artistic, literary and scientific knowledge for the benefit of individual and collective improvement.

As for professors, the criteria were to be a nurse, to be in the teaching profession with minimum experience of one year, to be responsible for subjects that, according to the course coordinators, have content about violence in the syllabus. And, as regards the managers, they should participate in the coordination of courses, extension project, research, internship activities in practice fields, and be in the teaching exercise. However, the managers participating in the research, although they were also professors, did not respond to professors' interviews, thus constituting as exclusion criteria. All guests accepted to participate in the survey.

The choice of the Nursing course is due to the fact that it is recognized as a social practice, by the work process centered on individual and collective care, common to clinical, educational, administrative/managerial practice, committed to the attention to the individual, family and community, in a plural context of needs and demands. ${ }^{25}$ The choice is also due to the importance of this professional in the care of women in situations of SA. ${ }^{26}$

$\mathrm{HEI} A$ is a private institution located in a municipality with 188,233 inhabitants, which has been presenting significant advances in basic education in the national scenario. ${ }^{23} \mathrm{HEI} B$ is an educational foundation in the state capital, with a population of approximately 2,680 million. Both offer the course over 10 semesters, with equivalent workload, meeting the DCNs for undergraduate nursing.

Between March and November 2018 data was collected through semi-structured interviews, conducted individually by the first author, a nurse, assisted by an undergraduate student, who received previous training to perform this activity. Information was collected at the HEls' facilities, in a private room, with a previously scheduled time and day, and an average duration of 25 minutes.

The participants were identified by the letter $\mathrm{P}$ (professor), A (student, aluno in Portuguese) and G (manager, gestor in Portuguese), followed by the number corresponding to the order of participation in the interviews, plus the institutional link to $\mathrm{HEI} A$ or HEI B. The speeches were recorded in smartphones, transcribed in full by the interviewers who, after the collection was completed, undertook to disclose the research results to the HEls participating in the study.

As the analytical theoretical reference for the discussion of the results, 'gender violence' ${ }^{12}$ and 'rape culture' were adopted. ${ }^{13}$ For the orientation and organization of the information, content analysis in the thematic modality was used. ${ }^{22}$ The themes emerged after the distribution, in the table, of the respondents corresponding speeches and extraction of meaning units, later context units and, finally, the elaboration of the themes: conceptions about SA against women; SA approach against women in vocational training, and limits and possibilities of the insertion of the topic in the nursing curriculum.

The project was approved by the respective Research Ethics Committees of the institutions: Higher Institute of Applied Theology - INTA, under Opinion No. 3,234,478, and the University of Fortaleza, with Opinion No. 2,108,403. All participants signed the Informed Consent Form. 


\section{RESULTS}

\section{Characterization of the study participants}

The survey had 27 key informants among students, professors and managers of the two higher education institutions. Of these, $81 \%$ are female, with ages ranging from 21 to 52 years old, and a mean age of 33.1 years old. Regarding marital status, $41 \%$ (11) are single, $48 \%$ (13) are married and $11 \%(3)$ are divorced. As for religion, $89 \%$ report being Catholic. Among professors and managers, the teaching practice ranged from four to 13 years.

\section{Conceptions on SA against women}

It is recurrent in the speeches the reiteration that SA against the woman visible in society is evidenced by the physical and/ or psychological manifestations. The statements point to the severity of the phenomenon as they associate the concept of violence with death and injury. They also considered the complexity and overlapping of violence that surrounds women by also situating verbal and moral aggressions, in addition to patrimonial violence:

Act consisting of death or injury (...) a physical, psychological violence that happens against most women (A3 $H E I-A)$.

It may be a physical aggression, such as a verbal and moral aggression, that hits this woman; even property violence can be a type of violence for this woman (P4 $H E I-A)$.

A reproduction of the macho culture was also observed, blaming women for the violence suffered from the established relations of domination:

Insignificant moments of violence she's letting go and this is taking another turn in her life, [...] I think the woman is raped because she lets herself be raped (G1 HEI - A).

I believe it also goes a lot from women's perception and permission (G3 HEI - A).

However, the understanding of other participants about SA against women pointed to a closer approach to conceptual and legislative advances, recognizing the permanence of power and oppression relations, which deny female autonomy and the consequent exercise of sexual and reproductive rights:

Sexual assault against women goes beyond the physical act itself. I used to think it was just body-related rape, but today I think until you say something, call her some term she doesn't like, to me that's sexual assault (A5 HEI - B).
I consider any action in which the person, using a position of power, using physical force or coercion, intimidation or some psychological influence, she compels another person to have or witness or participate in any way to sexual interactions or anything that may in any way hurt her sexuality (P1 HEI - B).

It is any sexual act that he does not consent to, regardless of being with his partner or not (P2 HEI - B).

That's all she is obliged to; she didn't give permission to happen (G1 HEI - B).

The participants understood that SA against women is a consequence of power, force and domination in society, which treats men and women asymmetrically and is perpetuated for generations:

I see violence against women as unfair because we have long lived in a macho society (A2 HEI - B).

The woman has always been subjected to this [SV] (A5 $H E I-A)$.

The participants emphasize multifactoriality in the genesis of violence against women, in which one of the manifestations, SA, is often "legitimized" by "male domination" through the unequal distribution of culturally accepted power in society.

The causes are multifactorial, not necessarily just one, but I will highlight some principles that is the cultural process, which places man with status and power (P2 HEI - A).

Would define [...] with a single word: cowardice. Prejudice, of a society that has always devalued women, thinking that women are always inferior (G3 $\mathrm{HEl}-\mathrm{A}$ ).

\section{Approach to SA against women in vocational training}

Still incipient theoretical and methodological approaches to SA against women in undergraduate nursing were recursive in students' statements. Although identifying the insertion of the topic in the scope of research and extension activities as components of vocational training, in the students' understanding, the topic appears diluted in modules that cover dispersed content or presented as a theme that requires a crosssectional approach, inscribed in the matrix curriculum.

When considering the theoretical-conceptual gap in Nursing graduation, the participants' testimonies attest to the absence or incipience unknown about SA against women:

I' $m$ in the sixth semester and no classes have been given on this matter (A1 HEI - A). 
No, violence we don't approach much. Violence is not basically addressed at all during the academic now (A3 $H E I-B)$.

No, there is no discipline! I already studied because I participated in the Violence League, so I started studying about it (A4 HEI - B).

On the other hand, speeches were observed of students who remember this approach, even superficially and including the various types of violence against women. It was pointed out that some professors spoke even about the "Maria da Penha" Law, thus indicating an approach to the legal aspects surrounding $S A$ :

The types of domestic violence were briefly addressed [...] against women, they even approached the "Maria da Penha" Law, but it was very superficial (A5 HEI - A).

It didn't exactly focus on the matter, but some of my professors, when they talk about collective health, which addresses various topics, have already addressed various subjects, including sexual assault (A3 HEI - A).

When referring to teaching, research and extension that materialize the differential of $\mathrm{HEl}$ in vocational training, preparing professionals to meet social demands, professors and students recognized the existence of extension programs and projects, with approaches on the theme and, in these activities, pupils are able to play a "shy" role:

At times, there are conferences on nursing care for women in situations of violence and technical visits to the support network for women in situations of violence, directed by the professor (P1 HEI - B).

At the time I was in the internships, we went to develop one of the actions in one of the health units that dealt with sexual assault against women (A2 HEI - A).

In the Violence League [of study], I started to study about it (A4 HEI - B).

The professors' statements reinforce that discussions and possible deepening of the subject may emerge in research activities, especially in study and/or research groups, whose topics are linked to the confrontation and occurrences of SA. The thematic axes of these groups approach sexual and reproductive rights in different ways, as well as the repercussions on the mental health of women and families:

I know there is a research group that is Sexual and Reproductive Health, and I believe that this topic should be addressed (P1 HEI - $A$ ).
My Mental Health research group, we deeply address violence, not just the theoretical approach, but [...] also produces research in this regard $(P 2 \mathrm{HEI}-A)$.

In the speeches of the managers of the Nursing courses, a consensual discourse is identified that the topic is presented as transversal in the curricular syllabus, stressing that these discussions are taken up in the modules and/or disciplines directed to women's health in general. Participants add that the existence of seminars fosters new debates on the topic.

Within the disciplines of the various undergraduate courses, we have cross-sectional disciplines, the disciplines that address such a topic, the issue of racism, violence against women, and also the disciplines that are directed at women's health. and at certain moments of the discipline, seminars are held addressing sexual assault (G1 HEI - A).

In Women's Health this is worked on, violence against women. When you also work in Collective Health, you work in the various areas of violence, you can also work in the transversal Health and Disease Process; but, so, I think it has the disciplines, the direct curricular contents like Women's Health and it has the transversal , that this violence could be worked on (G2 HEI - A).

Well, if I understand curriculum content as some specific discipline I would say no, but if I understand curriculum content as content that can be worked on in one or several disciplines, I would say yes, because there is transversality and not only in the course of nursing but in all courses. We have these cross-curricular contents that address various topics, and one of those topics is exactly this issue of raising awareness about violence against women and violence in general. So I would say yes, we have content, not in the form of disciplines, but in the form of transversal topics that address these issues. (G3 HEI - A).

A manager clarifies the implementation of the integrated curriculum and the inclusion of complex topics, previously discussed in a timely manner or simply not debated, to cross the curriculum structure during the course of academic education. Among these topics, violence has generally been selected and has been successful in these approaches.

Since 2012, we have implemented an integrated curriculum, with a lot of content that until then was viewed very punctually or often unseen, and we are managing to permeate some themes, and one of the themes that the course chose at the time as a transversal theme was violence in general. Today it is discussed since the third semester (G1 HEI - B). 


\section{Difficulties and possibilities of inserting the topic in the Nursing curriculum}

When discussing the difficulties of inserting the topic in the curriculum syllabus of Nursing courses, students and professors centralized the speeches on the taboos involving female sexuality. These refer to the challenge of women playing multiple roles in society and enjoying their autonomy in the exercise of sexuality.

I think there is still a lot of taboo, so when it involves women, then there is even more taboo, because you are talking about violence and talking against women and still talking about sexuality (A1 HEI - B).

You are already growing up in that macho, taboo-like environment and you think talking about sexuality is such a supernatural thing. So, it is difficult for you to pass on to the student this issue of sexuality and violence, because there are women who think that...? She is married and has to be submissive and that is it. This is a violence act ( $A 2 \mathrm{HEI}-B)$

In any context, bringing up discussions involving the topic of SA is complex. The topic is constructed and reproduced from a culture rooted in power relations and intertwined with other challenging social issues. Considering that it is a course that is predominantly female in its path, whose participants are also inserted in the context of gender inequalities, the professor points out the difficulty in approaching the topic.

It is a difficult topic to address because it involves cultural issues that are very strong and social issues that end up in the debate. What I can see is that our student groups are predominantly female ( $P 2 \mathrm{HEI}-\mathrm{B})$.

Added to this, the controversy which settles in the classroom environment by finding or supposing that talking about SA may confront or upset students who have experienced violent situations at some point in their lives. This concern is expressed in the speeches of professors and course managers of one of the institutions.

It's a very controversial topic, so sometimes we get emotional with some students, because some have already been through this situation (P3 HEI - A).

Even we have had cases of sexual assault by our academics, which we really had to intervene, because it was also making learning difficult. We came to find out that was the reason. So, this is a highly sensitive subject that involves a lot the family side, the personal side. We have experienced both the problem and we have also experienced the difficulty of touching this issue within a class because it is a controversial topic (G1 HEI - A).
This manager reaffirms the difficulty on the part of teachers to approach the topic shifting the meaning and understanding of subjectivities and experiences by appropriating the concepts, technical and legal devices. In this situation, the silence pact is signed:

Many professors prefer not to talk about it, and the student who, in turn, has gone through something that will remember or that will touch a sore spot of what happened, also do not want others to touch it, so the difficulty is due to this, the professor does not want to go through that path and the student, in turn, who has some sequel to it, also does not want to talk, and ends up not being a topic much discussed within the university (G1 HEI - A).

An understanding is identified that, while recognizing the importance of culture and macho as a cause of SA, distorts the approach on the topic in professional training, blaming women for the reproduction of machismo.

I think there is a cultural issue, we still live in a society that is machista. So even the woman is extremely macho. I think there's the cultural issue yet, that no one should poke their nose into a husband-and-wife fight! (G1 HEI - B).

On the other hand, one can see in the speech of a professor the concern with social demands, represented here by SA against women, which needs to be understood by society, regarding the multiple causes and repercussions. This understanding permeates the institutional relations in the macro and micropolitical spaces, which urge for implications of professionals in the search for their confrontation.

The biggest difficulty I see is that violence is seen as a public health problem. Still for the health sector, although some discussion is under discussion [...] this preference for the still biomedical model of health still remains, a challenge is to generate in professors and students this broader view in various spaces and scenarios ( $P 1$ $H E I-B)$.

It is important to point out that students and professors express the desire that the topic should be discussed beyond the classroom, become visible and extend to the community, where women are part of a cultural context, whose gender inequality prevails and influences opinions and behaviors. With this concern to disseminate debates on the topic in extramural spaces, students and professors point out possible paths in discussions about SA, even with a still repressive character, disregarding the need for empowerment and protagonist of women in facing SA: 
This should be portrayed in the community, because many women suffer violence and we do not know, because many of them do not report it, so it would be good to take to the community, make a guiding blitz, talk about these laws dynamically, to cause impact on these women so that they can report and know their rights (A5 HEI - A).

They add the urgency of discussing the topic in the course of professional training in all disciplines, preparing them to deal with complex realities, based on qualified scientific and technical knowledge. As it has been approached in a student's speech, it adds little, because 'what you have learned, everyone knows':

I believe this should be emphasized from the beginning of graduation because you hear about women's violence only in the women's health discipline onwards [...] (A2 HEI - B).

I think that each discipline should talk a little bit about violence, for example, women's health, talk a little about violence against women, the health of children and teenagers, also talk about violence. Because it is not only sexual, there is the psychological, the physical, the violence of the elderly. I think that in all or almost all disciplines should address the topic. Talk at least a little, because people would be getting more familiar, because talking quickly in a discipline, I think it is very brief, so there is no way to learn. I learned almost nothing; I learned the basics that I think anyone knows ( $A 4 \mathrm{HEI}$ - B).

We have to move forward in this discussion, talk more about it, to break down these barriers that exist even with professionals, to talk about the theme (P5 IES - B).

It also identifies a manager's concern about how recognize institutional scenarios to address the topic of SA in the HEI, adding that there is no appropriation of knowledge in the Nursing course; this knowledge is based on the training of the social worker, because social constructions are present in the curricula of these courses.

I think the biggest difficulty lies in recognizing the spaces within the institution in order to insert disciplines, forum and moments of discussion. I think the difficulty is to have ownership of the topic in order to disseminate knowledge, actions within the institution, so I think that is the difficulty. If you take the social service, it is very strong, so it works very well, because it is part of its content, even in its construction, the social relations [...] (G5 HEI - A).

The speech warns of the insufficiency of discussions in the Nursing course on topics that challenge society. This absence weakens the training of qualified professionals to assist women in SA situations who experience different social contexts.

\section{DISCUSSION}

The conceptions presented lack complex and broader debates in the HEls, to influence the qualification of nurses professional education regarding the knowledge about SA against women.

It is noteworthy that, although most of the research participants are female, the reproduction of discourse and patriarchal conceptions in female speech converge to the subjection of women before the naturalization of attitudes and thoughts characterized as a global social phenomenon, i.e., the source of discourse does not interfere with the way of analyzing the object of study by differentiating gender from respondents. This understanding can be identified in the verbalization of manager 1 and manager 3 , both from HEI A, as transcribed in the results.

It is known that SA against women is evident as a complex and multidimensional phenomenon, which may lead to the impotence of professionals to conduct situations involving the topic, as the lack of knowledge regarding the social and psychological aspects of victimized individuals and clinical and biological conditions. ${ }^{27}$

In the academic trajectory, university students identified as violent those behaviors that caused visible or physical damage, referring to corporal violence as the most recognized, moral and psychological violence against women were the most present in the courtship among respondents, followed by sexual, physical and patrimonial. ${ }^{28}$ These results highlight the importance of including gender equality debates with respect to the limits established in interpersonal relations.

There are cultural resistances in approaching the issue with patients, prevailing the biological model, to the detriment of the precepts of integrality, often attributing the recognition of SA to physical and superficial injury. ${ }^{25,29-31}$ Given this premise, the need for qualification of vocational training focusing on the social and health interests of the population is considered. For this, it is important to ensure the insertion of the topic gender violence, and its different expressions, in the minimum curriculum, based on the need of the community, recognizing that the HEls have an important role to broaden the discussion in academic spaces and enable the understanding of unequal construction between genders. ${ }^{30,31}$

There is a certain lack about the inclusion of content that discuss the SA identified from the students' experiences during disciplinary practices. However, HEI managers considered the multidisciplinarity that surrounds the topic and revealed that the content approach is transversal in the undergraduate course, besides being also contemplated in some research and extension strategies.

It was identified that the inclusion of SA in the curricula would be at the mercy of the subjectivity of the professor because, as it was found in some lectures of this study, discussing complex and interconnected topics that involve approaches to sexuality and gender issues are contrary to the world view of these professors. 
In this sense, the incipience of this discussion ${ }^{32}$ stems from the lack of the topic of SA in the academic curricula of nursing and other areas of health and social work, whose consequences imply the fragmentation of adequate care, enhanced by the lack of knowledge of women in situations of sexual assault.

In contrast, in other testimonies, the study participants mentioned some guidelines for disseminating the SA issue against women as a health problem, and it is necessary to awaken society and professionals who assist women in SA situation for this topic.

The nurse can greatly contribute to the care of women in situations of $S A$, as she plays a central role in access to the health services, and may be the first contact of this woman in the search for protection and care network. Therefore, it is essential that this professional is sensitive to welcoming with qualified listening, the identification of signs and symptoms not verbalized and the management of comprehensive and resolute attention.

Studies carried out involving the practice of nurses in coping with SA against women recommend the following: promoting prevention and coping actions against $\mathrm{SA}$, with dissemination of cores and referral centers; seeking, with managers, greater attention to this topic; requesting training, teaching materials and actions with the community; systematically including the study of SA during the graduation of nurses, guaranteeing students the opportunity to participate in the care of women in situations of violence; and training professionals of the Basic Health Units to know how to deal with the theme safely and decisively. ${ }^{17,25,33,34}$

However, a study ${ }^{35}$ conducted with health professionals from a primary care service to analyze professional practices in health care for women in situations of violence, warns of the 'psychologization of violence'. The authors report that professionals understand that the best and most appropriate care for these women is referral to psychology and mental health services, because, according to then, the resolution of issues related to situations experienced by women in SA situations would be directed to the Psychology service, recognized as qualified to address complex situations. ${ }^{35,36}$

This position reflects the fragility in health education that, despite sharing fields, does not integrate collaborative content and practices, capable of reducing the fragmentation of attention to individuals, families and communities. ${ }^{31,34-36}$

It is detected in some speech postures that require a critical reflection on the difficulties of approaching the $\mathrm{SA}$ issue against women, not only in the settings of educational institutions, but expanding to Brazilian society. Thus, the importance of preparing professionals for an integral approach and in the perspective of sexual and reproductive rights is emphasized, capable of promoting the integration of knowledge and practices derived from different fields of knowledge, which complement each other and present interceptions for the promotion of women's health.

Contributing to this discussion is a study conducted in the city of Fortaleza (CE), Brazil, which, from the participants speeches, found that the priority care to SA situations with women was imputed to the social worker, considering the training anchored in social rights, ${ }^{34}$ reiterating findings identified in this research in which nursing curricula do not generally prepare future professionals to deal with phenomena that contribute to the health sector and that have roots in social determinants.

Maintaining obstacles and silence in the face of realities that permeate the territories and health care points in the course of academic education is to maintain the reification of an unequal culture that denies the rights and autonomy of the individuals. It is to retroact in the achievements and advances in the construction of theoretical and legal frameworks in facing SA against women.

Also noteworthy is the difficulty of educators in finding spaces for discussion, adopting a short time for the dialog of psychosocial topics in women's health care. However, it is necessary to identify barriers that prevent a sufficient approach to gender-based violence in women's health to inspire solutions and embrace them in the curricula. ${ }^{36}$

In this sense, the analysis of student testimonials suggests options to overcome the problems and difficulties of approaching the theme in the teaching-learning and practical scenarios, such as incorporating the content of violence against women across all disciplines, since the beginning of the undergraduate course. Added to this is the reinforcement in the speeches about the need to disseminate guidance on laws, existing services and the protection and support network in the communities, through extension activities, practice modules and professional practice, empowering women to deconstruct gender inequalities.

The process of academic education, based on the DCNs, needs to be grounded in the perspective of making the individual able to think reflexively and critically, innovating and creating, with autonomy, solutions to the challenges presented in daily life. Thus, this process is the development of a critical citizen, capable of facing the rapid changes of knowledge and respective reflexes in the world of work.

Diverse studies ${ }^{37-39}$ indicate that the difficulty of health professionals in dealing with violence in daily practice occurs because they do not perceive certain episodes as situations of violence and for fear of signaling to the team the identified cases, evolving to an empty service and discontinuous treatment, which entails a second violence in care, which should welcome and point the way to protection, with rights guaranteed.

When considering the powerlessness in cases of violence, the need for training on gender studies to professionals is also understood, to provide autonomy and effective action in the face of such situations, not being restricted to referral, in the absence of physical injuries ${ }^{30,35}$ and/or sporadic care..$^{40}$

This study should be expanded to other higher education institutions in other states and regions, in order to include discussions and diversity in approaching the topic in multiple curricular matrices in the academic formation of the future nurse. 


\section{FINAL CONSIDERATIONS}

The theme of SA against women in the HEls has been approached in a fragmented and differentiated way in different academic contexts. Those involved in the investigation find it difficult to approach the theme due to its multifaceted character, involving subjective and cultural questions about gender inequalities.

However, the research reveals possibilities for the insertion of spaces for reflection on the theme in the education of nurses, which should be started from the beginning of the undergraduate course, transversalizing the entire course and extending to the community through the dissemination of practices that empower women to face SA, thus allowing deconstruction of the gender inequalities present in society.

Indeed, the implementation of approaches to violence against women, emphasizing sexual violence as one of the most relentless manifestations of gender violence, in the course of vocational training and praxis, potentiates the resignification of the patriarchal culture and points out possibilities for confronting the rape culture.

Although the research has only contemplated two HEls in the Northeast region, this study opens new horizons to broaden and deepen the discussion on the theme in academic environments in Brazil. The findings support further discussions and align with the opportune moment when it is discussed the reorientation of curricular guidelines for health courses.

\section{REFERENCES}

1. Redding EM, Ruiz-Cantero MT, Fernández-Sáez J, Guijarro-Garvi M. Gender inequality and violence against women in Spain, 2006-2014: towards a civilized society. Gac Sanit [Internet]. 2017 mar/apr; [cited 2018 oct 02]; 31(2):82-8. Available from: https://doi.org/10.1016/j. gaceta.2016.07.025

2. Semahegn A, Mengistie B. Domestic violence against women and associated factors in Ethiopia; Systematic review. Reprod Health [Internet]. 2015 aug; [cited 2018 oct 10]; 12(1):78. Available from: https:// doi.org/10.1186/s12978-015-0072-1

3. Sen S, Bolsoy N. Violence against women: prevalence and risk factors in Turkish sample. BMC Womens Health [Internet]. 2017 nov; [cited 2018 oct 15]; 17(1):100. Available from: https://doi.org/10.1186/s12905-0170454-3

4. Adjah ESO, Agbemafle I. Determinants of domestic violence against women in Ghana. BMC Public Health [Internet]. 2016 may; [cited 2018 oct 20]; 16:368. Available from: https://doi.org/10.1186/s12889-0163041-x

5. CONVENÇÃO INTERAMERICANA para prevenir, punir e erradicar a violência contra a mulher - Convenção de Belém do Pará, 1994. Disponível em: http://www.cidh.org/Basicos/Portugues/m.Belem. do.Para.htm Acesso em: 29/10/2019.

6. Sundborg E, Törnkvist L, Saleh-Stattin N, Wändell P, Hylander I. To ask, or not to ask: the hesitation process described by district nurses encountering women exposed to intimate partner violence. J Clin Nurs [Internet]. 2017; [cited 2018 oct 24]; 26(15-16):2256-65. Available from: https://doi.org/10.1111/jocn.12992
7. Torralbas-Fernández A, Calcerrada-Gutiérrez M. Using Primary Care to Address Violence against Women in Intimate Partner Relationships: Professional Training Needs. MEDICC Rev [Internet]. 2016 oct; [cited 2018 oct 28]; 18(4):38-41. Available from: https://www.ncbi.nlm.nih.gov/ pubmed/27829653

8. Rocha BD, LanderdahI MC, Cortes LF, Vieira LB, Padoin SM. Violence against women: perceptions of nursing students' about the focus on the formation. Invest Educ Enferm [Internet]. 2015; [cited 2018 dec 05]; 33(2):260-8. Available from: https://www.ncbi.nlm.nih.gov/ pubmed/26535842

9. Gaspar RSP, Lopes MU. Evolução da notificação de violência sexual no Brasil de 2009 a 2013. Cad Saúde Pública [Internet]. 2018; [cited 2018 dec 10]; 34(11):e00172617. Available from: http://dx.doi. org/10.1590/0102-311x00172617

10. Silva PLN, Almeida SG, Martins AG, Gamba MA, Alves ECS, Silva Júnior RF. Educational practices in the training of university students regarding violence against women. Rev Bioét [Internet]. 2016 aug; [cited 2018 dec 15]; 24(2):296-305. Available from: http://dx.doi.org/10.1590/198380422016242128

11. Bradbury-Jones $\mathrm{C}$, Broadhurst $\mathrm{K}$. Are we failing to prepare nursing and midwifery students to deal with domestic abuse? Findings from a qualitative study. J Adv Nurs [Internet]. 2015 apr; [cited 2019 dec 25]; 71(9):2062-72. Available from: https://doi.org/10.1111/jan.12666

12. Saffioti HIB. Contribuições feministas para o estudo da violência de gênero. Cad Pagu [Internet]. 2001; [cited 2019 jul 02]; (16):115-136. Available from: $h$ ttps://dx.doi.org/10.1590/S0104-83332001000100007

13. Sousa RF. Cultura do estupro: prática e incitação à violência sexual contra mulheres. Rev Estud Fem [Internet]. 2017 apr; [cited 2019 jul 02]; 25(1):9-29. Available from: http://dx.doi.org/10.1590/18069584.2017v25n1p9

14. Porto RTS, Bispo Júnior JP, Lima EC. Violência doméstica e sexual no âmbito da Estratégia de Saúde da Família: atuação profissional e barreiras para o enfrentamento. Physis [Internet]. 2014 sep; [cited 2018 dec 29];24(3):787-807. Available from: http://dx.doi.org/10.1590/S010373312014000300007

15. Martini JG, Massaroli A, Lazzari DD, Luz JH. Currículos de cursos de graduação em enfermagem: revisão integrativa de literatura. Rev Pesqui Cuid Fundam [Internet]. 2017 jan/mar; [cited 2019 jan 05]; 9(1):265-72. Available from: $\mathrm{http}: / / \mathrm{dx}$.doi.org/10.9789/2175-5361.2017.v9i1.265-272

16. Ministério da Educação (BR). Diretrizes Curriculares Nacionais para a Educação Básica. Diversidade e Inclusão. Brasília (DF): MEC; 2013.

17. Cruz RAO, Araujo ELM, Nascimento NM, Lima RJ, França JRFS, Oliveira JS. Reflections in the light of the complexity theory and nursing education. Rev Bras Enferm [Internet]. 2017 feb; [cited 2019 jan 10]; 70(1):224-7. Available from: http://dx.doi.org/10.1590/0034-7167-2016-0239

18. Moraes MC. Relendo Paulo Freire a partir da complexidade e da transdisciplinaridade. In: Vieira AJH, Batalloso JM, Moraes MC organizador. A esperança da pedagogia: Paulo Freire - Consciência e compromisso. Brasília: Liber Livro; 2012. p. 67-102.

19. Ministério da Saúde (BR). Secretaria de Atenção à Saúde. Departamento de Ações Programáticas Estratégicas. Prevenção e tratamento dos agravos resultantes da violência sexual contra mulheres e adolescentes: norma técnica/Ministério da Saúde. Secretaria de Atenção à Saúde. Departamento de Ações Programáticas Estratégicas. Brasília (DF): Ministério da Saúde; 2012.

20. Senado Federal (BR). Secretaria Especial de Editoração e Publicações. Subsecretaria de Edições Técnicas. Lei Maria da Penha e Legislação Correlata. Dispositivos Constitucionais Pertinentes: Lei n. 11.340, de 7 de agosto de 2006. Brasília (DF): Senado Federal, Subsecretaria de Edições Técnicas; 2011.

21. Andrade MDL, Rhodus CC, Souza EF, Paim L, Carvalho W. O curso de graduação da escola de enfermagem da UFRJ - currículo pleno face ao parecer 163/72. Rev Bras Enferm [Internet]. 1973 sep; [cited 2019 jan 18]; 26(4-5):253-72. Available from: http://dx.doi.org/10.1590/0034716719730005000006 
22. Minayo MCS, Costa AP.Técnicas que fazem uso da palavra, do olhare da empatia - pesquisa qualitativa em ação. Aveiro, Portugal: Ludomedia; 2019.

23. Fontanella BJB, Ricas J, Turato ER. Amostragem por saturação em pesquisas qualitativas em saúde: contribuições teóricas. Cad Saúde Pública [Internet]. 2008 jan; [cited 2019 jan 18]; 24(1):17-27. Available from: https://dx.doi.org/10.1590/S0102-311X2008000100003

24. Portaria n. 1.350 de 16 de dezembro de 2018 (BR). Dispõe sobre as Diretrizes para as Políticas de Extensão da Educação Superior Brasileira. Diário Oficial da União [Internet], Brasília (DF). 17 dez 2018: Seção 1: 34; [cited 2019 jul 4]. Available from: http://portal.mec.gov.br/ docman/novembro-2018-pdf/102551-pces608-18/file

25. Acosta DF, Gomes VLO, Oliveira DC, Gomes GC, Fonseca AD. Aspectos éticos e legais no cuidado de enfermagem às vítimas de violência doméstica. Texto Contexto - Enferm [Internet]. 2017; [cited 2018 jan 23]; 26(3):e6770015. Available from: http://dx.doi. org/10.1590/0104-07072017006770015

26. Silva LMP, Ferriani MGC, Silva MAI. Atuação da enfermagem frente à violência sexual contra crianças e adolescentes. Rev Bras Enferm [Internet]. 2011 oct; [cited 2019 jan 26]; 64(5):919-24. Available from: http://dx.doi.org/10.1590/S0034-71672011000500018

27. Baigorria J, Warmling D, Neves CM, Delziovo CR, Coelho EBS. Prevalence and associated factors with sexual violence against women systematic review. Rev Salud Publica [Internet]. 2017 nov/dec; [cited 2019 feb 06]; 19(6):818-26. Available from: http://dx.doi.org/10.15446/ rsap.v19n6.65499

28. Souza TMC, Pascoaleto TE, Mendonça ND. Violência contra mulher no namoro: percepções de jovens universitários. Rev Psicol Saúde [Internet]. $2018 \mathrm{dec}$; [cited 2019 jul 09]; 10(3):31-43. Available from: http://dx.doi.org/10.20435/pssa.v10i3.695

29. Dourado SM, Noronha CV. Marcas visíveis e invisíveis: danos ao rosto feminino em episódios de violência conjugal. Ciênc Saúde Colet [Internet]. 2015 sep; [cited 2019 feb 15]; 20(9):2911-20. Available from: http://dx.doi.org/10.1590/1413-81232015209.19012014

30. Bezerra JF, Silva RM, Cavalcanti LF, Nascimento JL, Vieira LJES, Moreira GAR. Conceitos, causas e repercussões da violência sexual contra a mulher na ótica de profissionais de saúde. Rev Bras Promoç Saúde [Internet].2016 jan/mar; [cited 2019 feb 19]; 29(1):51-9. Available from: $h$ ttp://dx.doi.org/10.5020/18061230.2016.p51

31. Cordeiro KCC, Santos RM, Gomes NP, Melo DS, Mota RS, Couto TM. Formação profissional e notificação da violência contra a mulher. Rev Baiana Enferm [Internet]. 2015 jul/sep; [cited 2019 feb 23]; 29(3):20917. Available from: http://dx.doi.org/10.18471/rbe.v29i3.13029
32. Pinto LW, Mendes CHF, Nascimento M, Campos D. Violência contra as Mulheres: antigas questões, novas configurações. In: Minayo MCS, Assis SG, organizadoras. Novas e Velhas Faces da Violência no Século XXI: visão da literatura brasileira do campo da saúde. Rio de Janeiro (RJ): Editora Fiocruz; 2017. p. 203-222.

33. Baptista RS, Chaves OBBM, França ISX, Sousa FS, Oliveira MG, Leite CCS. Violência sexual contra mulheres: a prática de enfermeiros. Rev Rene [Internet]. 2015 mar/apr; [cited 2019 feb 27]; 16(2):210-7. Available from: http://dx.doi.org/10.15253/2175-6783.2015000200010

34. Vieira LJES, Silva ACF, Moreira GAR, Cavalcanti LF, Silva RM Protocolos na atenção à saúde de mulheres em situação de violência sexual sob a ótica de profissionais de saúde. Ciênc Saúde Colet [Internet]. 2016 dec; [cited 2019 mar 05]; 21(12):3957-65. Available from: http://dx.doi.org/10.1590/1413-812320152112.15362015

35. Almeida LR, Silva ATMC, Machado LS. O objeto, a finalidade e os instrumentos do processo de trabalho em saúde na atenção à violência de gênero em um serviço de atenção básica. Interface [Internet] 2014; [cited 2019 mar 10]; 18(48):47-60. Available from: http://dx.doi. org/10.1590/1807-57622014.0560

36. Schaffir J, Waddell V, Watson D, Way D. National survey on psychosocial obstetrics and gynecology curriculum in US medical schools. J Psychosom Obstet Gynaecol [Internet]. 2014 jun; [cited 2019 mar 16]; 35(2):37-41. Available from: http://dx.doi.org/10.3109/016748 2X.2014.912210

37. Delziovo CR, Coelho EBS, d'Orsi E, Lindner SR. Violência sexual contra a mulher e o atendimento no setor saúde em Santa Catarina - Brasil. Ciênc Saúde Colet [Internet]. 2018 may; [cited 2019 mar 18]; 23(5):1687-96. Available from: http://dx.doi.org/10.1590/141381232018235.20112016

38. Gupta J, Falb KL, Ponta O, Xuan Z, Campos PA, Gomez AA, et al. A nurse-delivered, clinic-based intervention to address intimate partner violence among low-income women in Mexico City: findings from a cluster randomized controlled trial. BMC Med [Internet]. 2017 jul; [cited 2019 mar 22]; 15(1):128-140. Available from: https://doi.org/10.1186/ s12916-017-0880-y

39. Crombie N, Hooker L, Reisenhofer S. Nurse and midwifery education and intimate partner violence: a scoping review. J Clin Nurs [Internet]. 2016 jul; [cited 2019 mar 25];26(15-16):2100-25. Available from: https:// doi.org/10.1111/jocn.13376

40. Nielson MH, Strong L, Stewart JG. Does Sexual Assault Nurse Examiner (SANE) Training Affect Attitudes of Emergency Department Nurses Toward Sexual Assault Survivors? J Forensic Nurs [Internet]. 2015 jul/sep; [cited 2019 mar 28]; 11(3):137-43. Available from: https:// doi.org/10.1097/JFN.0000000000000081

\footnotetext{
a The study integrates the research "Comparative analysis of the approach to sexual assault against women in health professional training in different universities", with partnerships between four HEls in Brazil: Federal University of Rio de Janeiro (Universidade Federal do Rio de Janeiro, UFRJ, University of Fortaleza-UNIFOR, State University of Ceará (Universidade Estadual do Ceará, UECE) and University Center INTA (UNINTA), under the coordination of Professor Ludmila Fontenele Cavalcanti.
} 